\title{
Applying the social-ecological system framework to the diagnosis of urban lake commons in Bangalore, India
}

\author{
Harini Nagendra $^{1,2}$ and Elinor Ostrom ${ }^{2}$
}

\begin{abstract}
The south Indian city of Bangalore provides a challenging yet representative context within which to examine issues of governance of urban social-ecological commons. The city was once famous for its numerous large water bodies, which have witnessed tremendous encroachment and pollution in recent years. These water bodies, called tanks or lakes, were typically managed by adjacent village communities but are now administered by a number of government departments involved with aspects of lake management, with multiple overlapping jurisdictions. The public's perceptions of lakes has also changed with urbanization, transitioning from community spaces valued for water and cultural services to urban recreational spaces used largely by joggers and walkers. We focus on a set of seven lakes located in the urbanizing peripheral areas of southeast Bangalore. Some water bodies have been restored and managed effectively by newly forged collaborations between citizens and local government. Others are extremely polluted, and some have completely dried up and have been encroached. We use a social-ecological system (SES) framework to investigate why some locations have been successful in negotiating changes in governance from community-based systems to state management following urbanization, whereas other lakes have deteriorated. We use seven second-tier SES variables that were associated with self-organization in previous research: size of resource system, number of actors, leadership, social capital, importance of resource, existence of operational-choice rules, and existence of informal mechanisms for monitoring. We also include three third-tier variables previously identified as important in urban lake commons in Bangalore: scale and type of pre-existing pollution, exclusion of socioeconomic groups from the planning process, and networking with government organizations. We use this subset of 10 variables to examine social outcomes of the lakes, which we define as the extent of collective action by residents working together for lake restoration and ecological outcomes based on the ecological condition of the lakes. Collective action was low in only one of seven lakes, which challenges the presumption that citizens will not organize efforts to cope with common-pool problems. However, only two of seven lakes were highly successful in regard to both the extent of collective action and the level of ecological performance. While one lake was small and the other moderate in size, these two cases shared similar ranking in all other variables. Both lakes were polluted at a relatively low level compared with the other lakes, and in both cases, the leaders of local groups were able to network with government officials to clean up the lakes. Unfortunately, the challenge of cleaning up urban lakes after many decades of pollution is very difficult without effective interaction with various governmental units. Our analysis illustrates the usefulness of the SES framework in examining the combination of variables that makes a collective difference in affecting the outcomes of collective action and ecological performance. Our findings illustrate the need for polycentric arrangements in urban areas, whereby local residents are able to organize in diverse ways that reflect their own problems and capabilities, but can also work jointly with larger-scale governments to solve technical problems requiring changes in major engineering works as well as acquiring good scientific information. Such arrangements can reduce transaction costs for city governments by actively engaging local communities in processes that include coordination of collective activities, design of inclusive and locally suited ecological and social restoration goals, and planning and enforcement of regulations limiting access and withdrawal. At a time when many city governments are facing financial and administrative challenges that limit their ability to regulate and maintain urban commons, models of public-community partnerships could provide more inclusive, equitable, and sustainable institutional alternatives. This is an aspect that needs significant further consideration because the attention of most urban planners and scholars has remained on privatization while studies of successful instances of cooperative action in the urban context remain few and far between.
\end{abstract}

Key Words: collective action; decentralization; leadership; peri-urban SES; polycentricity

\section{INTRODUCTION}

We are witnessing an era of large-scale urbanization. More than half of the world's population now lives in cities, and human settlements continue to expand rapidly in area and increase in population density across all continents (United Nations 2011). Yet the most dramatic changes in urbanization are set to take place largely in developing countries, in particular, in the continents of Africa and Asia (Montgomery 2008, Seto et al. 2011). Rural to urban transformations in these regions of the world are associated with extensive land-use modification coupled with dramatic increases in consumption levels (Huang et al. 2010). These transformations lead to ecological degradation as well as high levels of pressure on ecosystem services (DeFries and Pandey 2010), with obvious social consequences (Faeth et al. 2012).
Compounding these challenges is the mismatch between current institutions and ecological dynamics, a gap that is widening due to urbanization and the consequent increased separation between humans and nature in cities (Folke et al. 2007, Colding 2012).

Of the multiple ecosystem services supplied by urban areas, fresh water is especially critical, indeed essential, for human survival in cities across the globe (Economics of Ecosystems and Biodiversity 2011). However, this resource is especially affected by urbanization. Thus, by 2050, seasonal water shortages are predicted for as many as 3 billion urban dwellers across the globe (McDonald et al. 2011). Institutions and governance will play key roles in ensuring better adaptation to these challenges, yet these have been explored little compared to technical and engineering solutions (Huang et al. 2010, Economics of Ecosystems and 
Biodiversity 2011). Surface water bodies such as freshwater lakes can be critical in this context, for instance, in India. Many freshwater ecosystems such as lakes, rivers, and wetlands are managed as common-pool resources in rural areas across the world (Ostrom 2007). Although their ownership has (often fairly recently) been transferred to state authorities, many urban commons such as wetlands, lakes, and forests continue to be accessed by local communities for traditional cultural and livelihood uses as well as by recent urban migrants for aesthetic and recreational purposes (D'Souza and Nagendra 2011, Garnett 2012). In most cases, users of urban commons lack formal ownership over the lands they access, but frequently have access to other bundles of property rights; that is, withdrawal, management, and/or exclusion (Agrawal and Ostrom 2001, Colding 2012).

Urban commons play an especially critical role in governance in recently urbanized areas at the peri-urban fringe, especially in developing countries. Reliance on ecosystem resources is frequently higher in peri-urban and rural areas compared to cities (DeFries and Pandey 2010). However, the persistence of ecological commons in the urban fringe has been challenging, in large part because of the tendency of city municipalities and government agencies to centralize their control over natural resources and ecosystems. This is ironic, as many authors (e.g., Colding 2012) have argued that urban commons are very important, not just for their capacity to provide improved local ecosystem governance, but also for their capacity to bridge the human-nature gap in cities and to foster a culture of environmental stewardship.

Challenges of governance are especially critical in peri-urban fringe areas, which constitute unique social-ecological transitional spaces with a mix of rural and urban characteristics (Simon 2008). Peri-urban areas constitute centers of increased social heterogeneity, often leading to fragmentation of existing social networks (Nicholls 2008). Peri-urban residents often have to deal with a confusing mix of rural and urban institutions, policies, and laws, where the locus of control over local commons shifts to a different level (that of the city municipality), simultaneously creating an environment in which opportunities for dialog and cooperation between different levels of government are scarce (Narain and Nischal 2007). Urbanization in the periphery of cities thus frequently leads to periods of "regulatory slippage" (Foster 2011) during periods of rapid growth, coupled with insufficient administrative and financial infrastructure, when city governments face challenges of reduced capacity to control access to commons and regulate overuse.

In the fringe of cities, severe ecological and environmental challenges are thus often compounded by a widespread lack of implementation of planning norms and ineffective urban governance (Aguilar 2008). Yet ironically, efforts at conservation can be far more cost-effective and easier to implement in these locations, where land prices are often considerably less inflated than in the city, and where the trajectory of degradation is often recent and easier to reverse (Theobald 2004). Peri-urban areas thus also constitute areas of opportunity, where development has not yet taken place to its fullest expected extent, and where de facto governance of urban commons is still likely to vest with local communities, providing scope for better institutional governance (Colding et al. 2006, Elmqvist et al. 2013).
Thus, scholars and public officials interested in developing better institutions and policies for the governance of ecological commons in growing urban areas face a serious challenge because "a formal structure for institutional analysis has not been developed for urban ecosystem research" (Mincey et al. 2013:554). Addressing the complex problems of urban and rural resources at multiple scales cannot rely on one discipline alone because the causes and consequences of ecosystem degradation and recovery are both ecological and social. An interdisciplinary framework provides a common language that can be used when trying to understand the patterns of interactions and outcomes occurring in complex systems. The social-ecological system (SES) framework developed by Ostrom $(2007,2009)$ can be very useful for such analyses because it provides a common analytical language to diagnose the factors that are important for addressing the complex problems of urban and rural ecosystem management at multiple scales. The framework has been designed to apply to SESs that could range from lakes in Wisconsin (Brock and Carpenter 2007) and lobster fisheries in Maine (Wilson et al. 2007) to water institutions in Asia (Meinzen-Dick 2007), forests in Nepal (Nagendra 2007), and community-based conservation efforts across the world (Berkes 2007).

The utility of the SES framework for diagnosing the complex challenges related to the sustainable management of peri-urban and urban commons has not been explored thus far. Here, we provide an application of the SES framework to an urban context in India, a country experiencing particularly rapid urbanization in recent decades, with major impacts on ecosystems (DeFries and Pandey 2010, Nagendra et al. 2013). Urbanization-related changes in land use have led to pollution and degradation of lakes, concomitant with reduction in the social dependence of local communities on these freshwater resources, in many Indian cities, including Bangalore, Hyderabad, and Chennai (D'Souza and Nagendra 2011, Reddy et al. 2012, Merugu and Seetharaman 2013). We examine the effects of diverse structural variables on interactions and outcomes achieved related to seven urban lakes located at the fringe of the Indian city of Bangalore, an incipient megapolis that has undergone particularly rapid urbanization in recent years (Sudhira and Gururaja 2012).

Using the SES framework, we identify the combinations of variables associated with higher levels of self-organization and improved environmental conditions of a lake, relating these to studies using the SES framework in other contexts, as well as to other research on peri-urban and urban ecosystems. Based on our findings, we speculate about the challenges and opportunities for further research on the issue of urban collective action using the multi-tier SES framework.

\section{STUDY AREA}

The south Indian city of Bangalore has become famous internationally in recent years for its information-technology companies, even spawning a new word, "Bangalored," to indicate layoffs of multi-national employees whose jobs have moved to India. The city is India's third largest metropolis, with a population $>8.4$ million and an average annual population growth rate of $4.7 \%$ between 2001 and 2011. Bangalore has a much longer history than many realize, however, with evidence of human inhabitation at least as far back as 1000 BCE and an unbroken continuity of occupation since the early 16th century (Rice 1897a,b, Annaswamy 2003). 
Although Bangalore was once known for its wide tree-lined avenues, historic parks, and expansive water bodies, these natural resources have witnessed tremendous pressure in recent decades with the encroachment and pollution of water bodies, the felling of thousands of trees, and conversion of open areas and parks into commercial, industrial, and residential settlements (Nair 2005, Sudhira et al. 2007, Nagendra 2010, Nagendra and Gopal 2010). The expansion of the city's boundaries has also transformed the land-use patterns and governance of many of these natural spaces, with particular effects on water bodies. There were once thousands of reservoirs in the area surrounding Bangalore, which were used for a number of purposes, including agriculture, fishing, cattle washing, drinking, and domestic uses (Buchanan [1807] 1999). These water bodies, called tanks or lakes, were created by damming rain-fed streams to create networks of freshwater reservoirs topographically distributed throughout the region (Rice 1897a).

For centuries, these lakes were typically managed by adjacent village communities, with specific families and groups responsible for particular maintenance tasks such as desilting and maintenance of canals and tank bunds, and having access rights for fishing, irrigation, grazing, collection of fodder, and other natural resources. These rights and duties varied spatially and temporally across lakes and networks, with financial support sometimes provided by local elites, including temples and local chieftains (Buchanan [1807] 1999, Rice 1897a). Coerced labor was often used for the more labor-intensive tasks of tank construction and maintenance, and the spatial distribution of head- and tailend users reflected the existing, highly unequal social hierarchies of the times (Shah 2008).

Formal, uniform, and prescriptive rules replaced these specialized, spatio-temporal, adaptive rules by the end of the 19th century, when the British introduced irrigation and revenue departments. The number of government departments involved with aspects of lake management has now expanded to include the Bangalore Development Authority (BDA), Bangalore Water Supply and Sewerage Board, Department of Fisheries, Department of Minor Irrigations, Ecology and Environment Department, Karnataka Forest Department, Lake Development Authority, Karnataka State Pollution Control Board, and Bruhat Bengaluru Mahanagara Palike (BBMP, Bangalore's municipal government), with multiple overlapping jurisdictions (Gowda and Sridhara 2007, D'Souza and Nagendra 2011). The public's perceptions of lakes have also changed with urbanization, transitioning from community spaces valued for water and cultural services to urban recreational spaces used largely by joggers and walkers (Srinivas 2004, D'Souza and Nagendra 2011).

Currently, > 200 lakes are located within greater Bangalore (Bruhat Bangalore Mahanagara Palike 2010) while a much larger network of lakes surrounds the city at its periphery (Fig. 1). Rapid changes in land use have taken place around lake and wetland areas (D'Souza and Nagendra 2011); water bodies have been encroached by partial or total filling and conversion to urban land use, subjected to drying because of disruptions in drainage networks, and polluted from domestic and industrial waste (Environment Support Group 2009). Despite expensive government restoration projects, many lakes continue to be degraded, encroached for urban construction, silted, and contaminated by sewage (Sundaresan 2011). Recent attempts in a few lakes to explore public-private partnerships have also been extremely controversial, leading to uncontrolled disruptive activities such as motorized boating in some lakes, which have been effectively challenged by litigations by local individuals and nongovernmental organizations (Khandekar 2008).

Fig. 1. Distribution of lakes within and outside the city (municipality of Bruhat Bengaluru Mahanagara Palike), Bangalore, India. The inset indicates the focal area of study (see Fig. 2).

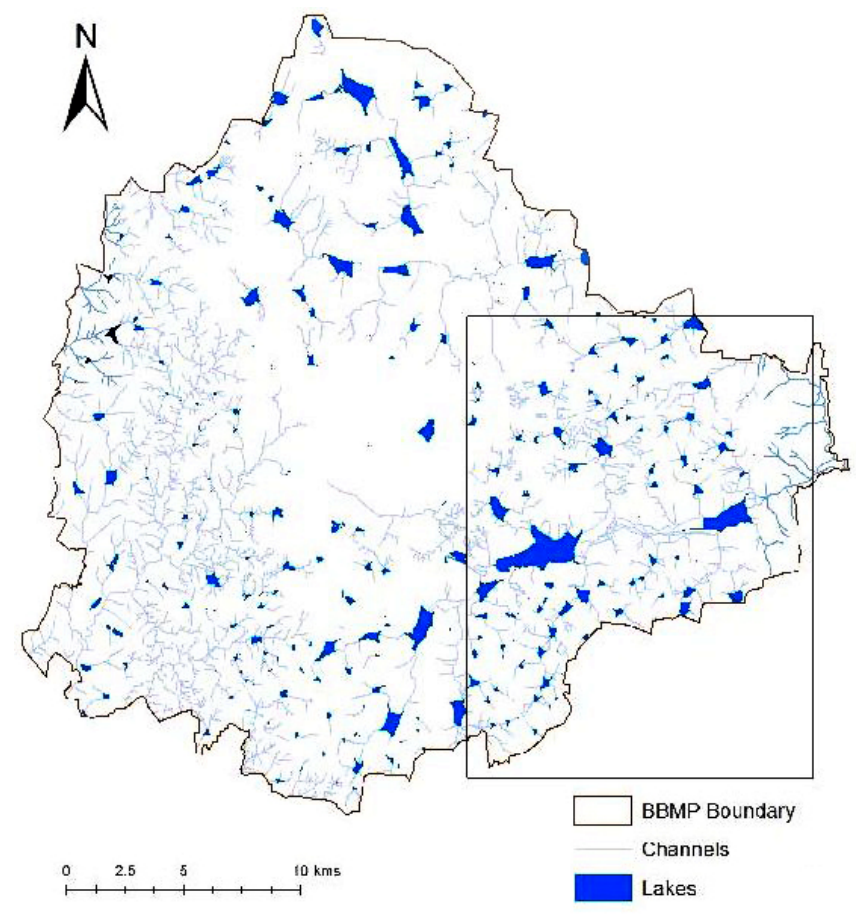

Here, we focus on the urbanizing peripheral areas of southeast Bangalore. Some water bodies have been effectively restored and managed by newly forged collaborations between citizens and local government (Nagendra 2010). Others are extremely polluted, and some have completely dried up and been encroached for construction. We use seven lakes located here as a lens to illustrate the usefulness of the SES framework as a diagnostic tool to investigate the combination of factors that might indicate why some locations have been successful while other lakes have deteriorated in ecological condition and/or failed in generating sufficient levels of collective action in the urban context. Bangalore provides a challenging context within which to examine these issues: a city struggling to deal with rapid urbanization, socio-cultural change, and deterioration in natural resources.

\section{METHODS}

The seven lakes considered in this case study form part of a lake network in the Koramangala-Challaghatta Valley of Bangalore (Fig. 2). One of us (HN) has been involved with lake mapping, assessment, restoration, and monitoring in this region since 2007 , engaging with informal, collaborative networks of local resident 
associations, researchers, and government organizations that have organized a number of activities focused around lake maintenance and restoration. Satellite remote-sensing data sets and topographical maps have been used to generate a spatial data set with information on the location, size, changes in size, and connectivity of the larger sub-network of lakes within which these are embedded, while personal observations and discussions with local communities living around and working on these lakes have provided a fairly detailed understanding of the social factors that might affect collective action. Field visits to each of these lakes have enabled qualitative recording of the ecological conditions based on plant and bird diversity, and visual indications of environmental disturbance, including observations of pollution, encroachment, and debris dumping at these lakes (see Nagendra et al. 2011 for further description of these lakes).

Fig. 2. Environmental and collective action outcomes between 2007 and 2012 for the seven lakes studied, Bangalore, India.

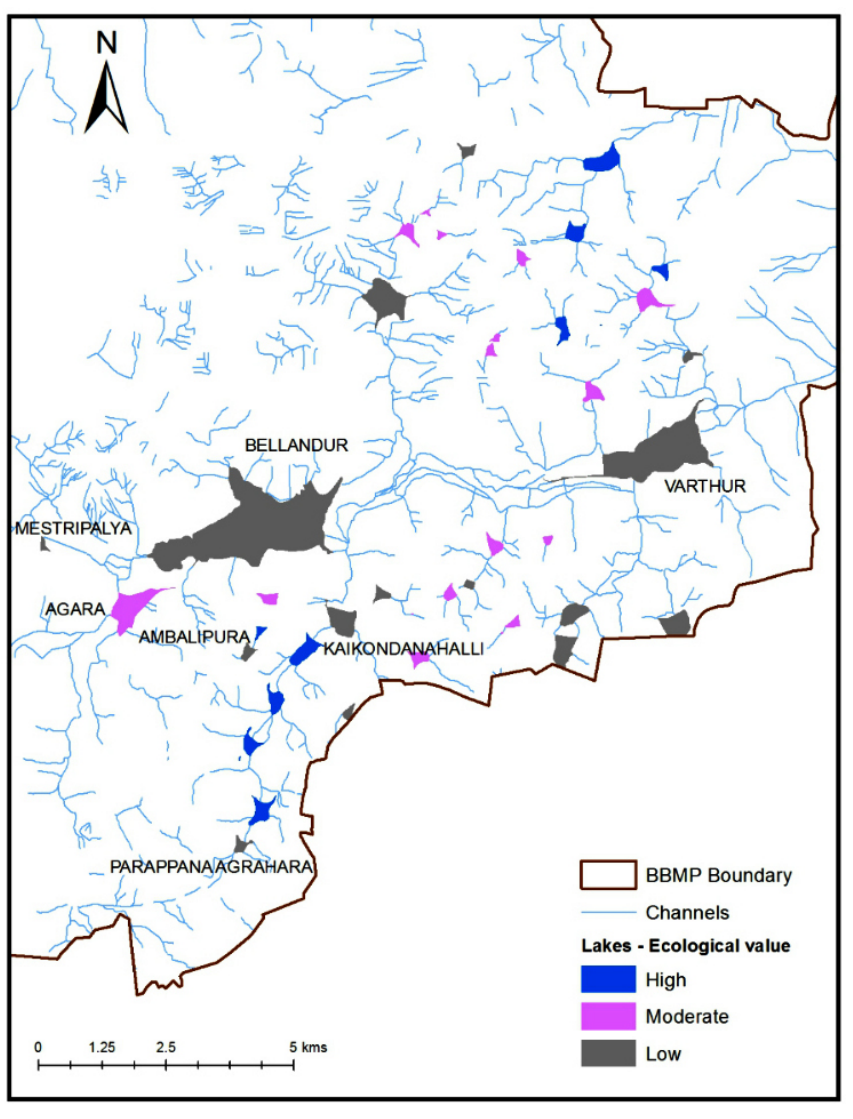

These lakes provide a useful set of contrasts in terms of challenges and opportunities for urban collective action and restoration, size, and condition (ecologically healthy to extremely polluted and completely dry). The social attributes of the residents around these lakes also differ, including substantial variation in the number of actors, levels of trust, and the nature of operational community rules. This divergence in social and ecological attributes in a relatively small set of lakes that are located quite near to each other enables us to obtain an in-depth understanding of some critical variables in the SES framework in an urban context.
The SES framework identifies the broad characteristics of Resource Systems and related Resource Units, Governance Systems, and Actors that together affect the structure of Action Situations leading to Interactions and Outcomes, as well as being embedded in Social, Economic, and Political Settings, and with Related Ecosystems (see Fig. 3). Within each of these broad structures are second-tier variables (Table 1). Within each secondtier variable are third-tier variables, and frequently, fourth- and fifth-tier variables.

Fig. 3. Basic structure of the social-ecological system framework. Source: McGinnis and Ostrom (2014).

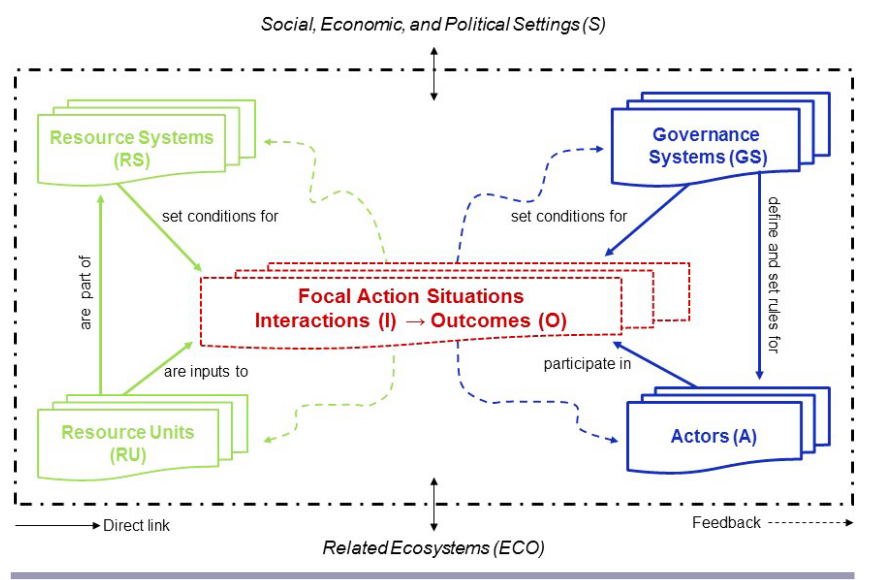

The SES framework identifies a large number of second- and third-tier variables. This nested hierarchy of variables was not proposed with the intent to suggest that all variables are relevant for all cases. Rather, analysts might find the SES framework helpful as a diagnostic tool that enables them to define clearly variables of interest and organize them into connected groups, as well as to ensure that they consider a broad universe of potentially applicable variables before identifying specific factors that are indicated as important based on existing field knowledge, previous research, or theoretical formulations.

In selecting the specific SES variables for our study (Table 1), our initial focus was on a subset of 10 second-tier variables identified by Ostrom (2009) to be associated with self-organization because self-organization forms an important focus of our study. Of these, based on our knowledge of the field context, five variables were considered relevant: RS3, size of resource system; A1, number of relevant actors; A5, leadership/entrepreneurship; A6, norms/ social capital; and A8, importance of resource. Here, we define social capital following Ostrom and Ahn (2003) as based on three attributes that are critical for research on collective action, namely, trustworthiness, the existence of networks, and the existence of rules and norms that enhance the ability of individuals to solve collective-action challenges. It should be noted that these differ, for instance, from definitions of social capital provided by other social scientists such as Bourdieu (1986) and Putnam (1993), who additionally consider the presence of durable, institutionalized networks that provide links with other institutions such as government agencies (Portes 1998).

The remaining five variables were not relevant to this context or provided redundant information. RS5, productivity of the system, tends to be strongly related with size and environmental 
Table 1. Explanation of variables in the social-ecological system (SES) framework, and description of the nine SES variables and two outcome criteria used in our study of lakes in Bangalore, India. Boldface font indicates variables included in our analysis; asterisks indicate factors suggested as important for collective action by Ostrom (2009:421).

\begin{tabular}{|c|c|c|c|}
\hline $\begin{array}{l}\text { Category } \\
\text { Variable } \\
\text { code }\end{array}$ & Variable name & Used in this study & Reason for inclusion/exclusion \\
\hline \multicolumn{4}{|c|}{ Social, Economic, and Political Settings (S) } \\
\hline S1 & $\begin{array}{l}\text { Economic } \\
\text { development }\end{array}$ & No & No appreciable variation across different lakes within the study \\
\hline S2 & Demographic trends & No & Same as above \\
\hline S3 & Political stability & No & Same as above \\
\hline S4 & $\begin{array}{l}\text { Other governance } \\
\text { systems }\end{array}$ & No & Same as above \\
\hline S5 & Markets & No & Same as above \\
\hline S6 & Media organizations & No & Same as above \\
\hline S7 & Technology & No & Same as above \\
\hline \multicolumn{4}{|c|}{ Related Ecosystems (ECO) } \\
\hline ECO1 & Climate patterns & No & Same as above \\
\hline $\mathrm{ECO} 2$ & Pollution patterns & No & Same as above \\
\hline $\mathrm{ECO} 3$ & $\begin{array}{l}\text { Flows into and out } \\
\text { of focal SES }\end{array}$ & No & Same as above \\
\hline \multicolumn{4}{|c|}{ Resource Systems (RS) } \\
\hline RS1 & $\begin{array}{l}\text { Sector (e.g., water, } \\
\text { forests, pasture, fish) }\end{array}$ & No & All lakes belong to the same sector \\
\hline $\mathrm{RS} 2$ & $\begin{array}{l}\text { Clarity of system } \\
\text { boundaries }\end{array}$ & & No appreciable variation across different lakes within the study \\
\hline RS3* & $\begin{array}{l}\text { Size of resource } \\
\text { system }\end{array}$ & Yes & $\begin{array}{l}\text { Identified as an important variable influencing collective action by Ostrom (2009); there } \\
\text { is substantial variation in size across lakes; size is a known important factor related to } \\
\text { lake position (upstream or downstream), lake productivity, and other factors related to } \\
\text { lake ecological condition in the study area }\end{array}$ \\
\hline RS4 & $\begin{array}{l}\text { Human-constructed } \\
\text { facilities }\end{array}$ & No & No appreciable variation across different lakes within the study \\
\hline RS5* & $\begin{array}{l}\text { Productivity of the } \\
\text { system }\end{array}$ & No & $\begin{array}{l}\text { Identified as an important variable influencing collective action by Ostrom (2009); } \\
\text { however, although there is substantial variation in the productivity of the system } \\
\text { across different lakes within the study, this variation is strongly linked with variable } \\
\text { RS3 (size of resource system), which is already included in the analysis }\end{array}$ \\
\hline RS6 & $\begin{array}{l}\text { Equilibrium } \\
\text { properties }\end{array}$ & No & $\begin{array}{l}\text { Although there is substantial variation in equilibrium properties across different lakes } \\
\text { within the study, this variation is strongly linked with variable RS3 (size of resource } \\
\text { system), which is already included in the analysis }\end{array}$ \\
\hline RS7* & $\begin{array}{l}\text { Predictability of } \\
\text { system dynamics }\end{array}$ & No & $\begin{array}{l}\text { Identified as an important variable influencing collective action by Ostrom (2009); } \\
\text { however, although there is substantial variation in the predictability of system } \\
\text { dynamics across different lakes within the study, this variation is strongly linked with } \\
\text { variable RS3 (size of resource system), which is already included in the analysis }\end{array}$ \\
\hline RS8 & $\begin{array}{l}\text { Storage } \\
\text { characteristics }\end{array}$ & No & $\begin{array}{l}\text { Although there is substantial variation across different lakes within the study, this } \\
\text { variation is strongly linked with variable RS3 (size of resource system), which is } \\
\text { already included in the analysis }\end{array}$ \\
\hline RS9 & Location & No & $\begin{array}{l}\text { The main parameter of location relevant to lake ecological condition is whether the } \\
\text { lake is located upstream or downstream; this parameter is strongly linked with } \\
\text { variable RS3 (size of resource system), which is already included in the analysis }\end{array}$ \\
\hline \multicolumn{4}{|c|}{ Resource Units (RU) } \\
\hline RU1* & $\begin{array}{l}\text { Resource unit } \\
\text { mobility }\end{array}$ & No & $\begin{array}{l}\text { Identified as an important variable influencing collective action by Ostrom (2009); } \\
\text { however, lakes in the Bangalore city jurisdiction are not managed with especial } \\
\text { attention to the availability of resource units (e.g., fish); thus, RU-related second-tier } \\
\text { variables were not considered in this study }\end{array}$ \\
\hline RU2 & $\begin{array}{l}\text { Growth or } \\
\text { replacement rate }\end{array}$ & No & Same as above \\
\hline RU3 & $\begin{array}{l}\text { Interaction between } \\
\text { resource units }\end{array}$ & No & Same as above \\
\hline
\end{tabular}




\begin{tabular}{|c|c|c|c|}
\hline RU4 & Economic value & No & Same as above \\
\hline RU5 & Number of units & No & Same as above \\
\hline RU6 & $\begin{array}{l}\text { Distinctive } \\
\text { characteristics }\end{array}$ & No & Same as above \\
\hline RU7 & $\begin{array}{l}\text { Spatial or temporal } \\
\text { distribution }\end{array}$ & No & Same as above \\
\hline \multicolumn{4}{|l|}{ Actors (A) } \\
\hline A1* & $\begin{array}{l}\text { Number of relevant } \\
\text { actors }\end{array}$ & Yes & $\begin{array}{l}\text { Identified as an important variable influencing collective action by Ostrom (2009), as } \\
\text { well as being important in the study area }\end{array}$ \\
\hline $\mathbf{A 2}$ & $\begin{array}{l}\text { Socioeconomic } \\
\text { attributes }\end{array}$ & $\begin{array}{l}\text { Yes (third-tier variable } \\
\text { A2a "Socioeconomic } \\
\text { groups excluded" is } \\
\text { examined within A2) }\end{array}$ & $\begin{array}{l}\text { Identified as an important variable influencing collective action in the literature; } \\
\text { important for the study area, where there are differences in the degree to which different } \\
\text { socioeconomic groups have been included in or excluded from lake use and management, } \\
\text { thus providing a specific aspect of socioeconomic attributes; this aspect was examined } \\
\text { as a third-tier variable within } \mathbf{A 2}\end{array}$ \\
\hline A3 & $\begin{array}{l}\text { History or past } \\
\text { experiences }\end{array}$ & No & No appreciable variation across different lakes within the study \\
\hline A4 & Location & No & Same as above \\
\hline A5* & $\begin{array}{l}\text { Leadership/ } \\
\text { entrepreneurship }\end{array}$ & Yes & $\begin{array}{l}\text { Identified as an important variable influencing collective action by Ostrom (2009); } \\
\text { specifically important for the study area }\end{array}$ \\
\hline A6* & $\begin{array}{l}\text { Norms (trust- } \\
\text { reciprocity)/social } \\
\text { capital }\end{array}$ & Yes & $\begin{array}{l}\text { Identified as an important variable influencing collective action by Ostrom (2009); } \\
\text { specifically important for the study area }\end{array}$ \\
\hline A $7 *$ & $\begin{array}{l}\text { Knowledge of SES/ } \\
\text { mental models }\end{array}$ & No & $\begin{array}{l}\text { Identified as an important variable influencing collective action by Ostrom (2009); } \\
\text { however, there is no appreciable variation across different lakes within the study }\end{array}$ \\
\hline A8* & $\begin{array}{l}\text { Importance of } \\
\text { resource (dependence) }\end{array}$ & Yes & $\begin{array}{l}\text { Identified as an important variable influencing collective action by Ostrom (2009); } \\
\text { specifically important for the study area }\end{array}$ \\
\hline A9 & $\begin{array}{l}\text { Technologies } \\
\text { available }\end{array}$ & No & No appreciable variation across different lakes within the study \\
\hline \multicolumn{4}{|c|}{ Governance Systems (GS) } \\
\hline GS1 & $\begin{array}{l}\text { Government } \\
\text { organizations }\end{array}$ & No & Same as above \\
\hline GS2 & $\begin{array}{l}\text { Nongovernmental } \\
\text { organizations }\end{array}$ & No & Same as above \\
\hline GS3 & Network structure & No & Same as above \\
\hline GS4 & $\begin{array}{l}\text { Property-rights } \\
\text { systems }\end{array}$ & No & Same as above \\
\hline GS5 & $\begin{array}{l}\text { Operational-choice } \\
\text { rules }\end{array}$ & Yes & $\begin{array}{l}\text { Identified as an important variable influencing collective action in the literature; } \\
\text { important for the study area, where there are substantial differences in the presence and } \\
\text { nature of operational rules developed and implemented by communities around different } \\
\text { lakes }\end{array}$ \\
\hline GS6 & $\begin{array}{l}\text { Collective-choice } \\
\text { rules }\end{array}$ & No & No appreciable variation across different lakes within the study \\
\hline GS7 & $\begin{array}{l}\text { Constitutional- } \\
\text { choice rules }\end{array}$ & No & Same as above \\
\hline GS8* & $\begin{array}{l}\text { Monitoring and } \\
\text { sanctioning rules }\end{array}$ & No & $\begin{array}{l}\text { Identified as an important variable influencing collective action by Ostrom (2009); } \\
\text { however, formal functioning rules for monitoring and sanctioning are not in place in } \\
\text { these lakes, whose formal governance is still largely dominated by state institutions }\end{array}$ \\
\hline \multicolumn{4}{|c|}{ Interactions (I) } \\
\hline $\mathrm{I} 1$ & Harvesting & No & No appreciable variation across different lakes within the study \\
\hline I2 & Information sharing & No & Same as above \\
\hline $\mathrm{I} 3$ & $\begin{array}{l}\text { Deliberation } \\
\text { processes }\end{array}$ & No & Same as above \\
\hline $\mathrm{I} 4$ & Conflicts & No & Same as above \\
\hline I5 & Investment activities & No & Same as above \\
\hline I6 & Lobbying activities & No & Same as above \\
\hline I7 & $\begin{array}{l}\text { Self-organizing } \\
\text { activities }\end{array}$ & No & Same as above \\
\hline I8 & Networking activities & $\begin{array}{l}\text { Yes (third-tier variable I8a } \\
\text { "Networking with } \\
\text { government" is examined } \\
\text { within I8) }\end{array}$ & $\begin{array}{l}\text { Identified as an important variable influencing collective action in the literature; } \\
\text { important for this study area, where there are substantial differences in the degree of } \\
\text { networking between local communities and government departments across different } \\
\text { lakes within the study; this aspect was examined as a third-tier variable within I8 }\end{array}$ \\
\hline I9 & Monitoring activities & Yes & $\begin{array}{l}\text { Identified as an important variable influencing collective action in the literature; } \\
\text { important for this study area, where there is substantial variation in the presence or } \\
\text { absence of informal mechanisms implemented by local communities for monitoring the } \\
\text { lake }\end{array}$ \\
\hline
\end{tabular}




\begin{tabular}{|c|c|c|c|}
\hline I10 & Evaluative activities & No & No evaluative activities systematically conducted across lakes within the study \\
\hline \multicolumn{4}{|c|}{ Outcome criteria $(\mathrm{O})$} \\
\hline O1 & $\begin{array}{l}\text { Social performance } \\
\text { measures (e.g., } \\
\text { efficiency, equity, } \\
\text { accountability, } \\
\text { sustainability) }\end{array}$ & Yes & $\begin{array}{l}\text { An important social outcome criterion for this social-ecological study is provided by the } \\
\text { degree of collective action }\end{array}$ \\
\hline $\mathbf{O 2}$ & $\begin{array}{l}\text { Ecological } \\
\text { performance } \\
\text { measures (e.g., } \\
\text { overharvested, } \\
\text { resilience, } \\
\text { biodiversity, } \\
\text { sustainability) }\end{array}$ & Yes & $\begin{array}{l}\text { An important ecological outcome criterion for this social-ecological study is provided by } \\
\text { the environmental condition of lakes }\end{array}$ \\
\hline $\mathrm{O} 3$ & $\begin{array}{l}\text { Externalities to other } \\
\text { SESs }\end{array}$ & No & $\begin{array}{l}\text { Externalities to other SESs were not considered within this study, which focused only } \\
\text { on collective action around the management of individual lakes }\end{array}$ \\
\hline
\end{tabular}

condition in Bangalore's lakes (Nagendra 2010). Three variables did not vary appreciably across our subset of seven lakes, making them less useful for this study: RS7, predictability of system dynamics; RU1, resource unit mobility; and A7, knowledge of SES/mental models. Variable GS6, collective-choice rules, was not relevant to our study because we focus on lakes within the city, where there are no formal rules dictating collective-choice outcomes. This process of selection thus provided us with five variables important for understanding self-organization.

We next examined literature applying the SES framework to collective action in a somewhat similar context of water-based commons, but with a focus on fisheries (Basurto and Ostrom 2009, Gutiérrez et al. 2011). Based on this, we identified one additional second-tier variable as important: GS5, operational-choice rules. Other literature also points to the importance of monitoring and sanctioning for self-organization and collective action (Ostrom 2005). In our study, formal, functional rules for monitoring and sanctioning (GS8) are not in place; however, some communities have developed and put into place informal mechanisms for monitoring (I9), which we consequently included in our study.

Finally, in further development of the SES framework, we added a consideration of two third-tier variables that have been demonstrated to be important in previous studies of urban lake commons in Bangalore (e.g., Environment Support Group 2009, Nagendra 2010, D’Souza and Nagendra 2011, Sundaresan 2011). Socioeconomic heterogeneity is an important theoretical variable for understanding self-organization (Poteete and Ostrom 2004). Previous research has indicated that the exclusion of specific socioeconomic groups such as fishers, fodder collectors, and migrant workers from collective action affects self-organization in the context of urban SESs, particularly with reference to urban water bodies (D'Souza and Nagendra 2011, Ellis 2011). This constitutes a specific sub-type of the second-tier variable A2, socioeconomic attributes of actors. Thus, we defined and incorporated a third-tier variable, A2a, into our analysis, describing whether specific socioeconomic groups have been excluded from the planning process. We added another third-tier variable, I8a, that characterizes a type of networking (with government) because previous research in urban contexts has demonstrated that networking with state organizations can be critical in many instances for effective collective action (Stoker 2000).

Thus, a final set of seven second-tier and three third-tier variables were used. We examined two kinds of Outcomes. O1 describes the social outcomes of the lake, which we define here as the extent of collective action by residents working together for lake restoration. We also described the lakes in terms of $\mathrm{O} 2$, their environmental condition (Appendix 1).

The SES matrix (Table 2) provides a temporal snapshot of selected social and ecological variables at the time of conducting the analysis. However, the social-ecological contexts and conditions experienced by these lakes are dynamic. Some of these lakes have changed fairly rapidly in recent years, especially the two recently restored lakes, Kaikondanahalli and Ambalipura. Thus, in addition to providing a one-time snapshot of the variables in the SES matrix, we also indicate some of the changes that have taken place over time in the table by adding + or - to cells for which the direction of the variable has changed in recent years.

\section{RESULTS}

The different SES variables can be described in terms of their potential action as barriers or facilitators of collective action and environmental restoration of lakes (Fig. 4). These variables provide us with useful insights into the design principles (Ostrom 2005) that can influence the likelihood of a lake to be the location of collective action and to undergo positive changes in environmental quality. Our analysis thus attempts to identify these variables (Fig. 4).

Lake size (RS3) constitutes a significant physical-ecological barrier to restoration. Bellandur and Varthur are among the largest lakes in Bangalore, collecting water, sewage outflow, and industrial effluents from a large watershed. Restoration of these lakes will be expensive because of the sheer volume of water received by these lakes and the technical and ecological challenges for restoration at this scale. For Agara and Kaikondanahalli, which represent mid-sized lakes, and Ambalipura, Parappana Agrahara, and Mestripalya, which are small lakes, estimated and actual costs of restoration have been much lower (Bruhat Bangalore Mahanagara Palike 2010), and these lakes represent a more manageable challenge. 
Table 2. Variables posited to have affected collective action and ecological performance between 2007 and 2012 for seven urban lakes in Bangalore, India. Boldface font indicates the two lakes for which both outcome variables showed an improvement over time.

\begin{tabular}{|c|c|c|c|c|c|c|c|c|}
\hline \multirow[b]{2}{*}{ Category } & \multirow[b]{2}{*}{ Variable } & \multicolumn{7}{|c|}{ Lake } \\
\hline & & Agara & Ambalipura & Bellandur & $\begin{array}{c}\text { Kaikondana- } \\
\text { halli }\end{array}$ & Mestripalya & $\begin{array}{c}\text { Parappana } \\
\text { Agrahara }\end{array}$ & Varthur \\
\hline $\begin{array}{l}\text { Resource } \\
\text { Systems (RS) }\end{array}$ & $\begin{array}{l}\mathrm{RS} 3 \text {, size of } \\
\text { resource } \\
\text { system }\end{array}$ & Moderate & Small & Large & Moderate & Small & Small & Large \\
\hline \multirow[t]{5}{*}{ Actors (A) } & $\begin{array}{l}\text { A1, number } \\
\text { of actors }\end{array}$ & Moderate & Moderate & Large & Moderate & Small & Moderate & Large \\
\hline & $\begin{array}{c}\text { A2-a, } \\
\text { socioeconomic } \\
\text { groups } \\
\text { excluded }\end{array}$ & Yes & No & No & No & Yes & No & No \\
\hline & $\begin{array}{c}\text { A5, } \\
\text { leadership }\end{array}$ & Lacking & Present & Present & Present & Present & Absent & Absent \\
\hline & $\begin{array}{l}\text { A6, norms of } \\
\text { trust, social } \\
\text { capital }\end{array}$ & Low & High & Moderate & High & Low & High & Moderate \\
\hline & $\begin{array}{l}\text { A8, } \\
\text { importance } \\
\text { of resource, } \\
\text { dependence }\end{array}$ & Low & Moderate (+) & Moderate & Moderate (+) & Low & High & Moderate \\
\hline $\begin{array}{l}\text { Governance } \\
\text { Systems } \\
(\mathrm{GS})\end{array}$ & $\begin{array}{c}\text { GS5, } \\
\text { operational } \\
\text { community } \\
\text { rules }\end{array}$ & Absent & Present (+) & Absent & Present (+) & Present & Absent (-) & Absent \\
\hline \multirow[t]{2}{*}{$\begin{array}{l}\text { Interactions } \\
\text { (I) }\end{array}$} & $\begin{array}{c}\text { I8a, } \\
\text { networking } \\
\text { with } \\
\text { government }\end{array}$ & Low & High (+) & Low & High (+) & Moderate & Low & Low \\
\hline & $\begin{array}{l}\text { I9, informal } \\
\text { norms for } \\
\text { monitoring }\end{array}$ & Absent & Present (+) & Absent & Present (+) & Absent & Absent (-) & Absent \\
\hline \multirow[t]{2}{*}{$\begin{array}{l}\text { Outcomes } \\
\text { (O) }\end{array}$} & $\begin{array}{l}\text { O1, social } \\
\text { performance } \\
\text { measure } \\
\text { (collective } \\
\text { action) }\end{array}$ & Moderate & High (+) & High & High (+) & High & Low (-) & Moderate \\
\hline & $\begin{array}{c}\mathrm{O} 2, \\
\text { environmental } \\
\text { performance } \\
\text { measure } \\
\text { (lake) }\end{array}$ & Low & High (+) & Low & High (+) & Low & Low (-) & Low \\
\hline
\end{tabular}

Note: (+) and (-) indicate recent changes from 2007 to 2012 in the direction indicated.

Social barriers to restoration can include the existence of a large (chaotic) or very small (insufficient for effective action) number of actors (A1), exclusion of specific socioeconomic groups (A2a), lack of leadership (A5), and/or low social capital (A6). Social barriers to restoration and maintenance are lowest in Kaikondanahalli and Ambalipura, where the diversity of actors is moderate, there is minimal exclusion of groups, and social capital is particularly strong with good leadership, following the recent process of lake restoration through community involvement (Amilineni 2011a,b). The set of actors is very large in Bellandur and Varthur, including the original villages, urban residents, industries, and hospitals located around these lakes. However, on the positive side, there has been no specific exclusion of local communities from planning, and at least in Bellandur, social capital and leadership are high, emanating from the original residents of these areas. In comparison, Mestripalya represents a complex case for restoration, having a very small set of actors involved, with original village inhabitants largely excluded from planning, although with high social capital within this group and strong leadership (Sundaresan 2011). 
Fig. 4. Schematic diagram of the social-ecological system barriers and facilitating variables that influence collective action and environmental restoration of lakes in Bangalore, India.

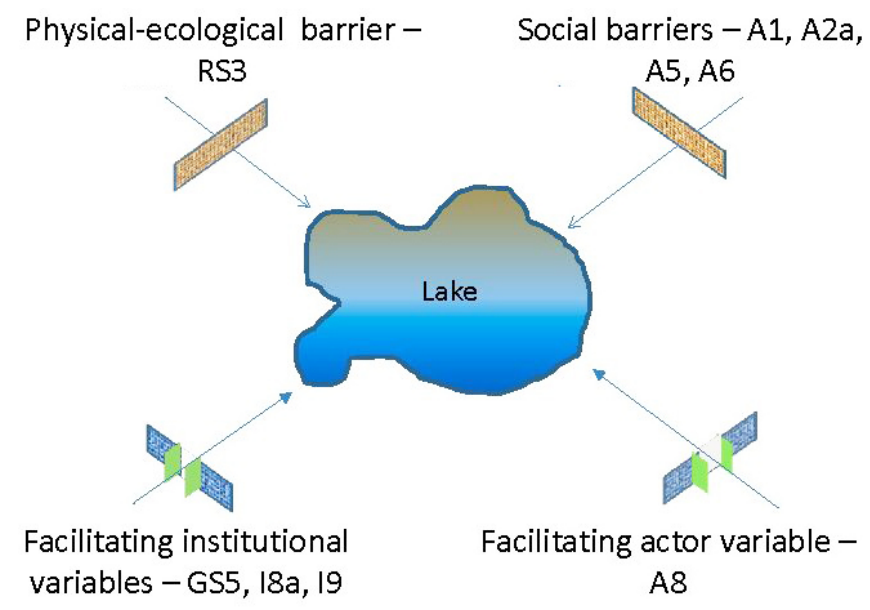

Dependence on the lake (A8) can provide a nucleating point for restoration and maintenance (Ostrom 2005) that can overcome physical, ecological, and social barriers. In Parappana Agrahara, the local village was, until recently, highly dependent on the lake for agriculture, cattle fodder collection, cattle washing, and groundwater recharge. In Bellandur, Varthur, and Parappana Agrahara, levels of motivation to restore the lakes are high because of moderate dependence on the lakes for agriculture and cattle fodder (although these dependencies have decreased over time), as well as for groundwater through wells located adjacent to these lakes. In Ambalipura and Kaikondanahalli, there are moderate levels of dependence for urban exercise, recreation, and groundwater recharge. Dependence is low in Agara, where the lake has been degraded for the past few years, as well as in Mestripalya, where the lakebed has been dry for decades.

The existence of operational community rules managing the types of activities permitted in the lake (GS5), informal norms related to monitoring (I9), and networking with government agencies (I8a) constitute institutional variables that can be critical for lake restoration and/or maintenance. All three are present in only two of the seven lakes: Ambalipura and Kaikondanahalli. Following restoration, the community association maintaining the lakes has developed an informal and evolving set of operational community rules, as well as informal norms of lake monitoring. This is missing from the other lakes, although such rules and norms are likely to have been in place during earlier times, when the local communities had greater control over lake management. Ambalipura and Kaikondanahalli have been especially successful at networking with the BBMP Lakes Division over the past five years for lake restoration and maintenance.

In terms of Outcome variables (O1), collective action is high in Ambalipura, Bellandur, Kaikondanahalli, and Mestripalya; moderate in Agara and Varthur, where some efforts have been made by local groups to protect and restore the lake; and low in
Parappana Agrahara, where local residents have tried to organize to protest against the pollution of their lake by the Bangalore Central Jail, but have been unable to do this effectively and in a sustained manner. Ambalipura and Kaikondanahalli are high in environmental condition (O2; see Appendix 1), whereas the other five lakes have low environmental condition. Since writing this article, however, efforts toward restoration of Agara lake have been initiated by local residents, providing an indication of potential further improvements in the condition of this lake. Further details on the SES attributes of these seven lakes are provided in Appendix 2.

Following Ostrom (2007), we do not use the SES variables to attribute causation of either collective action or environmental restoration as a consequence of specific variables present in these lakes. Direct establishment of causal relationships is challenging; similar to other complex systems, there are nonlinear interactions between variables, and many of these variables may be important or necessary, but not sufficient, and thus difficult to attribute causality to them (Ostrom 2007, 2009). Thus, this analysis provides an important step forward toward the understanding of how to achieve long-term sustainability of collectively managed lakes in the Bangalore context, but further work is required to understand relationships between different sets of variables and to posit potential causal relationships.

\section{DISCUSSION}

We describe the first application of the SES framework developed by Ostrom $(2007,2009)$ in an urban context, enabling us to assess the impact of the combination of nine different variables in determining the extent of collective action and positive environmental outcomes. We demonstrate the process that can be used for selection of SES variables relevant to a particular system (Table 1) and demonstrate how the framework can be further detailed to specify and examine the role of third-tier variables. Such details will be important in different contexts as the framework is developed further and applied to different SESs.

We find that only two of the seven lakes studied (Ambalipura and Kaikondanahalli) were successful in regard to both the extent of collective action and the level of ecological performance. While the size of Ambalipura was small and that of Kaikondanahalli was moderate, they shared similar rankings in all other variables: A1, number of actors was moderate; A2a, socioeconomic groups were not excluded; A5, local leadership was present; A6, trust and social capital were present; A8, the resource was moderately important to residents; GS5, operational community rules were present; I8a, networking with government officials occurred; and I9, informal norms for monitoring local uses of the lake were developed.

Comparison with the two lakes (Bellandur and Mestripalya) that have a high degree of collective action yet do not have positive ecological outcomes could help understand further the role of specific SES variables. The combination of barrier factors such as large size and high degree of pollution in Bellandur and low social capital and low dependence on the lake in Mestripalya seems to have played a role in limiting the transformation from collective action to positive environmental outcomes in these challenging urban conditions. Since writing this article, however, restoration has commenced in Mestripalya lake, due, in large part, to constant efforts of the local community around this lake. 
One additional variable that seems to be important is I8a. Networking between communities and the government appears to be an important variable that has an effect on the likelihood of collective action resulting in improved ecological condition of urban lakes, as witnessed by the fact that this variable is present in both lakes with high collective action and high ecological performance (Ambalipura and Kaikondanahalli) but lower or missing in lakes with moderate to high collective action but low ecological performance (Bellandur and Mestripalya). Bellandur is the largest lake in Bangalore, and a variety of actors and agencies are involved in polluting this lake, making the process of networking with the government an especially challenging task. In Mestripalya, a group of prominent local citizens formed contacts with the government, but as of 2012 were unable to make headway in initiating the process of lake restoration. Although newspaper reports have mentioned commencement of restoration in Bellandur over the past three years, no concrete action has taken place thus far. It is likely, although by no means certain, that Bellandur, like Mestripalya, will be restored to a better ecological condition in a few years as collective action by a diversity of local actors begins to make headway in spurring the administrative agencies involved in lake maintenance to take action.

Why is this important? Challenges of lake restoration include arresting land encroachment, clearing blocked inflow and outflow water channels, and preventing the continued dumping of solid waste and inflow of sewage and industrial effluents. Rejuvenation of a polluted lake also often requires the diversion of sewage through creation of a new channel that bypasses the lake, as well as dredging of the lakebed to remove accumulated silt and toxic waste. These activities are beyond the scope of citizen groups to manage unaided and require the involvement of a number of government agencies. While government agencies have the legal authority to prevent unwanted activities and harmful use of the lake, they may not know what is occurring at different locations soon enough to act in a timely manner. Further, local officials are often subject to governance incentives as well as incentives of political economy and rent-seeking that ensure that they are primarily accountable to higher officials or vested interests such as real estate agencies, rather than downward accountability to local communities or marginalized groups. Collective action, coupled with effective use of public opinion mobilized through actors such as the media, and with legal recourses through Public Interest Litigations, can help strengthen downward accountability, ensuring the effectiveness of monitoring against infractions and sanctioning of repeat-offenders. An example of this can be found in Kaikondanahalli lake, where repeated inflows of sewage from a neighboring apartment were finally addressed because of action by the BBMP, but which required constant follow up from the local citizens association (Amilineni 2011a).

Lake restoration efforts are also likely to be better designed to suit local social-ecological conditions when there is cooperation between local actors and government agencies. Government agencies such as the BBMP and BDA tend to contract out the task of lake restoration project reports to consultancy agencies, who often provide cookie-cutter or blueprint proposals for rejuvenation that fail to take into account the unique socialecological context and requirements of each lake (Gandhi 2011).
Citizen groups, in contrast, have in some cases networked very successfully with researchers, naturalists, and other technical experts to draft restoration plans tailored for each lake that take into account its specific social, institutional, and ecological setting (Nagendra et al. 2011). Thus, collaborations between local actors and government agencies can also be very fruitful for lake restoration, with local actors supplying the local knowledge about the lake and providing inputs about their requirements, while government agencies and their consultants provide the technical, financial, and manpower resources necessary for the task of dredging, bund building, and restoration. Local groups can also be very critical in monitoring the process of restoration and ensuring that the lake remains in healthy condition after rejuvenation (Amilineni 2011b).

\section{SPECULATION}

Thus far, we have discussed the potential for lake restoration in polluted peri-urban lakes, but to maintain lakes in good environmental condition and to ensure sustained collective action, sustained efforts at monitoring and maintenance will be required. In the Bangalore context, public interest litigations and active engagement by civic action groups, among which the Environment Support Group has played an especially prominent role, as well as positive action by the Karnataka courts, have been very critical in lakes being legally protected from encroachment or development for any purpose other than that of a public commons (Khandekar 2008, Environment Support Group 2009, High Court of Karnataka 2011). A legislative task force has also systematically documented widespread encroachments of lakes and water bodies for legal action by the government (Balasubramanian 2011). Thus, inputs from a diverse array of actors, including government agencies, citizen groups, researchers, naturalists, civic action groups, legislative groups, and the court, have been important in various ways such as for lake protection, rejuvenation, and maintenance. Concerns of equity and representation are important, and previous research shows that urban collective action can sometimes lead to the exclusion of certain groups (D'Souza and Nagendra 2011, Ellis 2011, Sundaresan 2011).

Other factors that have not been addressed in this analysis could also play important roles, for instance, differences in the level of encroachment of freshwater inflow channels into different lakes or the adequacy of infrastructure such as wastewater diversion channels. Thus, as indicated, this analysis does not seek to establish firm causality. Rather, given the limited exploratory nature of this analysis, we wish to identify potential factors that could be important for better institutional design, which can then provide insights for future study.

Based on the results from this initial study, we have initiated a quantitative application of the SES framework to a larger set of approximately 80 lakes in the southeastern section of Bangalore to gain a fuller picture of the relevant social and ecological conditions and the set of factors associated with building collective action among residents and with improved ecological performance. We also intend to investigate the relationship between the two outcome variables in more depth, which will add further nuance to our understanding of the SES framework. 


\section{CONCLUSIONS}

We applied the SES framework to examine the multiple social and ecological factors that potentially affect the level of collective action and ecological outcomes of seven of the many lakes located in Bangalore, India. Of the seven lakes, only two were highly successful in regard to both the extent of collective action and the level of ecological performance. While the size of Ambalipura was small and that of Kaikondanahalli was moderate, the two highly successful cases shared similar ranking in regard to all other variables. Unfortunately, the challenge of cleaning up urban lakes after many decades of pollution is very difficult without effective interaction with various governmental units. In both Ambalipura and Kaikondanahalli, the leaders of local groups were able to network with government officials to clean up their lakes. Leadership and trust were important in both of these lakes, as has also been demonstrated in other cases of collective action for environmental (sewage) management in the peri-urban areas of Chennai, India (Baud and Dhanalakshmi 2007), and in the case of co-managed fisheries around the world (Gutiérrez et al. 2011).

Our analysis generates several important lessons. First, it illustrates the usefulness of the SES framework in examining the combination of variables that makes a collective difference in affecting the outcomes of collective action and ecological performance. The framework provides us with a structured way to compare across cases with successful and unsuccessful outcomes to identify combinations of factors that act as barriers and facilitators for collective action and environmental restoration. In the peri-urban context, which poses particular challenges for collective action due to a number of factors, including heterogeneity of actors, a high degree of institutional fragmentation, and the dominance of statutory institutions (Stoker 2000, Swallow et al. 2006), our study provides insights for future participatory institutional co-design.

The results illustrate the need for polycentric arrangements (McGinnis 1999, 2011) whereby local residents are able to organize in diverse ways that reflect their own problems and capabilities but often need to work jointly with larger-scale governments to solve technical problems requiring changes in major engineering works as well as acquiring good scientific information (Baud and Dhanalakshmi 2007). The sustainable use and management of inland freshwater lakes in south India are associated with very high transaction costs (Ananda et al. 2006).

Our research demonstrates an approach of designing participatory institutions for lake governance that has been ignored in the urban context by many planners and policymakers but that can be especially important in rapidly developing cities with a large peri-urban fringe such as Bangalore (Mukhija 2005, Ananda et al. 2006, Colding 2012). Such an approach can reduce transaction costs for city governments by actively engaging local communities in processes that include coordination of collective activities, design of inclusive and locally suited ecological and social restoration goals, and planning and enforcement of regulations limiting access and withdrawal (Colding et al. 2006). At a time when many city governments are facing financial and administrative challenges that limit their ability to regulate and maintain urban commons (Lee and Webster 2006), a model of public-community partnerships could provide a more inclusive, equitable, and sustainable institutional alternative. This is an aspect that needs significant further attention; the attention of a majority of urban planners and scholars has remained almost exclusively on privatization, and there is limited research investigating the potential of alternate approaches that build on cooperative action in the urban context (Mukhija 2005).

Concurrently, across several countries in Asia, examples of participatory governance are beginning to emerge that involve engagement between urban communities and city government, introducing new polycentric institutional approaches that can be used as a foundation for practical lessons in new institutional design (Leonhardt 2012). Such partnerships typically have several important characteristics (Baud and Dhanalakshmi 2007). These include the existence of a long-term relationship that results in benefits to all actors, although these benefits need not be equal, and the existence of bargaining processes between actors that can result in instances of conflict as well as cooperation. Particularly important, as our research demonstrates, is the presence of effective networking between local communities and city government. This requires greater downward accountability. Diverse approaches can be envisaged to support increased downward accountability, including the provisioning of increased incentives for local officials who engage with communities such as through the incorporation of community feedback in performance reviews or through media publicity for motivated officials; the strengthening of independence and investigative powers for local ombudsman organizations such as the Lokayukta, an anti-corruption ombudsman; and the strengthening of alternative mechanisms for rapid settlement of grievances, such as the Lok Adalat or people's courts.

Responses to this article can be read online at: http://www.ecologyandsociety.org/issues/responses. $\mathrm{php} / 6582$

\section{Acknowledgments:}

Harini Nagendra acknowledges financial support from a Ramanujan fellowship from the Department of Science and Technology, Government of India, and from a USAID PEER grant. Elinor Ostrom acknowledges financial support from the National Science Foundation USA and from FORMAS through a program with Thomas Stern, University of Gothenburg, Sweden, on Human Cooperation to Manage Natural Resources (COMMONS). We also thank Mansee Bal, Pieter Bots, Cathie Carrigan, Rohan D'Souza, Sanchayan Nath, and two anonymous reviewers for their useful comments, and Joanna Broderick and Patty Lezotte for their excellent editing. This paper is dedicated to Elinor Ostrom, friend and colleague for so many years, in memory of our Tuesday conversations

\section{LITERATURE CITED}

Agrawal, A., and E. Ostrom. 2001. Collective action, property rights, and decentralization in resource use in India and Nepal. Politics and Society 29(4):485-514. http://dx.doi. org/10.1177/0032329201029004002

Aguilar, A. G. 2008. Peri-urbanization, illegal settlements and environmental impact in Mexico City. Cities 25(3):133-145. http:// dx.doi.org/10.1016/j.cities.2008.02.003 
Amilineni, S. 2011a. Sewage from building site, messing up Kaikondrahalli lake. Citizen Matters, September 14. [online] URL: http://bangalore.citizenmatters.in/blogs/show entry/3382sewage-from-sjr-construction-site-messing-up-kaikondrahalli-lake.

Amilineni, S. 2011b. We are forming a new Trust for Kaikondrahalli Lake! Citizen Matters, July 26. [online] URL: http://bangalore.citizenmatters.in/blogs/show entry/3209-new-trustfor-kaikondrahalli-lake-mapsas.

Ananda, J., L. Crase, and P. G. Pagan. 2006. A preliminary assessment of water institutions in India: an institutional design perspective. Review of Policy Research 23(4):927-953. http://dx. doi.org/10.1111/j.1541-1338.2006.00239.x

Annaswamy, T. V. 2003. Bengaluru to Bangalore: urban history of Bangalore from the pre-historic period to the end of the 18th century. Vengadam, Bangalore, India.

Balasubramanian, V. 2011. Task force for recovery of public land and its protection: greed and connivance. Chairman's report. Task Force for Recovery and Protection of Public Lands, Bangalore, India. [online] URL: http://bangalore.citizenmatters.in/docs/2011/ GoKVBalaTaskForceReport.pdf.

Basurto, X., and E. Ostrom. 2009. Beyond the tragedy of the commons. Economia delle fonti di energia e dell'ambiente 52 (1):35-60.

Baud, I., and R. Dhanalakshmi. 2007. Governance in urban environmental management: comparing accountability and performance in multi-stakeholder arrangements in South India. Cities 24(2):133-147. http://dx.doi.org/10.1016/j.cities.2006.11.003

Berkes, F. 2007. Community-based conservation in a globalized world. Proceedings of the National Academy of Sciences 104 (39):15188-15193. http://dx.doi.org/10.1073/pnas.0702098104

Bourdieu, P. 1986. The forms of capital. Pages 241-258 in J. G. Richardson, editor. Handbook of theory and research for the sociology of education. Greenwood Press, New York, New York, USA.

Brock, W. A., and S. R. Carpenter. 2007. Panaceas and diversification of environmental policy. Proceedings of the National Academy of Sciences 104(39):15206-15211. http://dx. doi.org/10.1073/pnas.0702096104

Bruhat Bangalore Mahanagara Palike. 2010. Namma Bengaluru Nisarga: an action plan for development of Bangalore's lakes. Bruhat Bangalore Mahanagara Palike, Bangalore, India.

Buchanan, F. [1807] 1999. A journey from Madras through the countries of Mysore, Canara, and Malabar, volume I. Reprint. Asian Educational Services, New Delhi, India.

Colding, J. 2012. Creating incentives for increased public engagement in ecosystem management through urban commons. Pages 101-124 in E. Boyd and C. Folke, editors. Adapting institutions: governance, complexity and social-ecological resilience. Cambridge University Press, Cambridge, UK. http:// dx.doi.org/10.1017/CBO9781139017237.008

Colding, J., J. Lundberg, and C. Folke. 2006. Incorporating greenarea user groups in urban ecosystem management. Ambio 35 (5):237-244. http://dx.doi.org/10.1579/05-A-098R.1
D’Souza, R., and H. Nagendra. 2011. Changes in public commons as a consequence of urbanization: the Agara Lake in Bangalore, India. Environmental Management 47(5):840-850. http://dx.doi.org/10.1007/s00267-011-9658-8

DeFries, R., and D. Pandey. 2010. Urbanization, the energy ladder and forest transitions in India's emerging economy. Land Use Policy 27(2):130-138. http://dx.doi.org/10.1016/j.

landusepol.2009.07.003

Economics of Ecosystems and Biodiversity. 2011. TEEB manual for cities: ecosystem services in urban management. Economics of Ecosystems and Biodiversity, Geneva, Switzerland. [online] URL: http://www.teebweb.org/publication/teeb-manual-for-citiesecosystem-services-in-urban-management/.

Ellis, R. 2011. Who's participation? Who's sustainability? A critical analysis of initiatives for urban sustainability in India. Scottish Geographical Journal 127(3):193-208.

Elmqvist, T., M. Fragkias, J. Goodness, B. Güneralp, P. J. Marcotullio, R. I. McDonald, S. Parnell, M. Schewenius, M. Sendstad, K. C. Seto, C. Wilkinson, M. Alberti, C. Folke, N. Frantzeskaki, D. Haase, M. Katti, H. Nagendra, J. Niemelä, S. T. A. Pickett, C. L. Redman, and K. Tidball. 2013. Stewardship of the biosphere in the urban era. Pages 719-746 in T. Elmqvist, M. Fragkias, J. Goodness, B. Güneralp, P. J. Marcotullio, R. I. McDonald, S. Parnell, M. Schewenius, M. Sendstad, K. C. Seto, and C. Wilkinson, editors. Urbanization, biodiversity and ecosystem services: challenges and opportunities. Springer, Berlin, Germany. http://dx.doi.org/10.1007/978-94-007-7088-1 33

Environment Support Group. 2009. Lakes: campaign against lake privatization in Bangalore. Karnataka Lokayukta calls for active public action to save Bangalore lakes. Report of workshop on "Urban lakes as ecological, cultural and public spaces." Environment Support Group (ESG) and Karnataka State Council for Science and Technology, Bangalore, India. [online] URL: http://static.esgindia.org/campaigns/lakes/action/ ESG UrbanLakesWorkshop Report 260909.html.

Faeth, S. H., S. Saari, and C. Bang. 2012. Urban biodiversity: patterns, processes and implications for conservation. $e L S$. Wiley, Chichester, UK. http://dx.doi.org/10.1002/9780470015902.a0023572

Folke, C., L. Pritchard, Jr., F. Berkes, J. Colding, and U. Svedin. 2007. The problem of fit between ecosystems and institutions: ten years later. Ecology and Society 12(1): 30. [online] URL: http:// www.ecologyandsociety.org/vol12/iss1/art30/.

Foster, S. R. 2011. Collective action and the urban commons. Notre Dame Law Review 87(1):57-133.

Gandhi, D. 2011. Lake rejuvenation or blueprint for real estate? The Hindu, January 11. [online] URL: http://www. thehindu.com/ todays-paper/tp-national/tp-karnataka/article1079273.ece.

Garnett, N. S. 2012. Managing the urban commons. University of Pennsylvania Law Review 160(7):1995-2189.

Gowda, K., and M. V. Sridhara. 2007. Conservation of tanks/ lakes in the Bangalore metropolitan area. Management of Environmental Quality 18(2):137-151. http://dx.doi. org/10.1108/14777830710725812 
Gutiérrez, N. L., R. Hilborn, and O. Defeo. 2011. Leadership, social capital, and incentives promote successful fisheries. Nature 470:386-390. http://dx.doi.org/10.1038/nature09689

High Court of Karnataka. 2011. Preservation of lakes in the city of Bangalore: report of committee constituted by the Hon'ble High Court of Karnataka to examine the ground realities and prepare an action plan for preservation of lakes in the city of Bangalore. High Court of Karnataka, Bangalore, India. [online] URL: https:// docs.google.com/viewer? $\mathrm{a}=\mathrm{v} \& \mathrm{pid}=$ explorer\&chrome $=$ true\&srcid=0BwFiFsEFJY-7YmMwMTE5OTItNzMzNy00YjIwLWJiYjUtN2NiOGU4ODN1NmFk\&hl=en US\&pli=1.

Huang, S.-L., C.-T. Yeh, and L.-F. Chang. 2010. The transition to an urbanizing world and the demand for natural resources. Current Opinion in Environmental Sustainability 2(3):136-143. http://dx.doi.org/10.1016/j.cosust.2010.06.004

Khandekar, S. 2008. High court stays privatization of lakes. Citizen Matters, November 5. [online] URL: http://bangalore. citizenmatters.in/articles/view/577-lake-protection.

Lee, S., and C. Webster. 2006. Enclosure of the urban commons. GeoJournal 66(1-2):27-42. http://dx.doi.org/10.1007/s10708-006-9014-3

Leonhardt, M. 2012. Together we are strong: networks, platforms and the social relations that support a people's process. Environment and Urbanization 24(2):481-496. http://dx.doi. org/10.1177/0956247812455771

McDonald, R. I., P. Green, D. Balk, B. M. Fekete, C. Revenga, M. Todd, and M. Montgomery. 2011. Urban growth, climate change, and freshwater availability. Proceedings of the National Academy of Sciences 180:6312-6317. http://dx.doi.org/10.1073/ pnas. 1011615108

McGinnis, M. D., editor. 1999. Polycentricity and local public economies: readings from the Workshop in Political Theory and Policy Analysis. University of Michigan Press, Ann Arbor, Michigan, USA.

McGinnis, M. D. 2011. Networks of adjacent action situations in polycentric governance. Policy Studies Journal 39(1):51-78. http://dx.doi.org/10.1111/j.1541-0072.2010.00396.x

McGinnis, M., and E. Ostrom. 2014. Social-ecological system framework: initial changes and continuing challenges. Ecology and Society 19(2): 30. http://dx.doi.org/10.5751/ES-06387-190230

Meinzen-Dick, R. 2007. Beyond panaceas in water institutions. Proceedings of the National Academy of Sciences 104 (39):15200-15205. http://dx.doi.org/10.1073/pnas.0702296104

Merugu, C. S., and R. Seetharaman. 2013. Comparative analysis of land use and lake water quality in rural and urban zones of south Chennai, India. Environment, Development and Sustainability 15(2):511-528. http://dx.doi.org/10.1007/s10668-012-9391-3

Mincey, S. K., M. Hutten, B. C. Fischer, T. P. Evans, S. I. Stewart, and J. M. Vogt. 2013. Structuring institutional analysis for urban ecosystems: a key to sustainable urban forest management. Urban Ecosystems 16(3):553-571. http://dx.doi.org/10.1007/s11252-013-0286-3

Montgomery, M. R. 2008. The urban transformation of the developing world. Science 319:761-764. http://dx.doi.org/10.1126/ $\underline{\text { science. } 1153012}$
Mukhija, V. 2005. Collective action and property rights: a planner's critical look at the dogma of private property. International Journal of Urban and Regional Research 29 (4):972-983. http://dx.doi.org/10.1111/j.1468-2427.2005.00632.x

Nagendra, H. 2007. Drivers of reforestation in human-dominated forests. Proceedings of the National Academy of Sciences 104 (39):15218-15223. http://dx.doi.org/10.1073/pnas.0702319104

Nagendra, H. 2010. Maps, lakes and citizens. Seminar India 613:19-23. [online] URL: http://www.india-seminar. com/2010/613/613 harini nagendra.htm.

Nagendra, H., and D. Gopal. 2010. Street trees in Bangalore: density, diversity, composition and distribution. Urban Forestry and Urban Greening 9(2):129-137. http://dx.doi.org/10.1016/j. ufug.2009.12.005

Nagendra, H., S. R. Sivaram, and S. Subramanya. 2011. Lakes of Mahadevpura constituency, Bengaluru: current status, changes in distribution, and recommendations for restoration. Report prepared for Bengaluru Bruhat Mahanagara Palike. Ashoka Trust for Research in Ecology and the Environment, Bangalore, India. [online] URL: http://www.atree.org/sites/default/files/ Mahadevpura report Feb2011 ATREE.pdf.

Nagendra, H., H. S. Sudhira, M. Katti, and M. Schewenius. 2013. Sub-regional assessment of India: effects of urbanization on land use, biodiversity and ecosystem services. Pages 65-74 in $\mathrm{T}$. Elmqvist, M. Fragkias, J. Goodness, B. Güneralp, P. J. Marcotullio, R. I. McDonald, S. Parnell, M. Schewenius, M. Sendstad, K. C. Seto, and C. Wilkinson, editors. Urbanization, biodiversity and ecosystem services: challenges and opportunities. Springer, Berlin, Germany. http://dx.doi.org/10.1007/978-94-007-7088-1_6

Nair, J. 2005. The promise of the metropolis: Bangalore's twentieth century. Oxford University Press, New Delhi, India.

Narain, V., and S. Nischal. 2007. The peri-urban interface in Shahpur Khurd and Karnera, India. Environment and Urbanization 19(1):261-273. http://dx.doi.org/10.1177/0956247807076905

Nicholls, W. J. 2008. The urban question revisited: the importance of cities for social movements. International Journal of Urban and Regional Research 32(4):841-859. http://dx.doi.org/10.1111/ j.1468-2427.2008.00820.x

Ostrom, E. 2005. Understanding institutional diversity. Princeton University Press, Princeton, New Jersey, USA.

Ostrom, E. 2007. A diagnostic approach for going beyond panaceas. Proceedings of the National Academy of Sciences 104 (39):15181-15187. http://dx.doi.org/10.1073/pnas.0702288104

Ostrom, E. 2009. A general framework for analyzing sustainability of social-ecological systems. Science 325:419-422. http://dx.doi.org/10.1126/science.1172133

Ostrom, E., and T. K. Ahn, editors. 2003. Foundations of social capital. Edward Elgar, Cheltenham, UK.

Portes, A. 1998. Social capital: its origins and applications in modern sociology. Annual Review of Sociology 24:1-24. http://dx. doi.org/10.1146/annurev.soc.24.1.1

Poteete, A. R., and E. Ostrom. 2004. Heterogeneity, group size, and collective action: the role of institutions in forest 
management. Development and Change 35(3):435-461. http://dx. doi.org/10.1111/j.1467-7660.2004.00360.x

Putnam, R. D. 1993. The prosperous community: social capital and public life. American Prospect 13(4):35-42.

Reddy, M. V., K. S. Babu, V. Balaram, and M. Satyanarayanan. 2012. Assessment of the effects of municipal sewage, immersed idols and boating on the heavy metal and other elemental pollution of surface water of the eutrophic Hussainsagar Lake (Hyderabad, India). Environmental Monitoring and Assessment 184(4):1991-2000. http://dx.doi.org/10.1007/s10661-011-2094-7

Rice, B. L. 1897a. Mysore: a gazetteer compiled for government, revisededition, volume I-Mysore in general. Archibald Constable, Westminster, UK.

Rice, B. L. 1897b. Mysore: a gazetteer compiled for government, revised edition, volume II-Mysore, by districts. Archibald Constable, Westminster, UK.

Seto, K. C., M. Fragkias, B. Güneralp, and M. K. Reilly. 2011. A meta-analysis of global urban land expansion. PLOS ONE 6: e23777. http://dx.doi.org/10.1371/journal.pone.0023777

Shah, E. 2008. Telling otherwise: a historical anthropology of tank irrigation technology in south India. Technology and Culture 49(3):652-674. http://dx.doi.org/10.1353/tech.0.0054

Simon, D. 2008. Urban environments: issues on the peri-urban fringe. Annual Review of Environment and Resources 33:167-185. http://dx.doi.org/10.1146/annurev.environ.33.021407.093240

Srinivas, S. 2004. Landscapes of urban memory: the sacred and the civic in India's high-tech city. Orient Longman, Hyderabad, India.

Stoker, G., 2000. Urban political science and the challenge of urban governance. Pages 91-109 in J. Pierre, editor. Debating governance: authority, steering, and democracy. Oxford University Press, Oxford, UK.

Sudhira, H. S., and K. V. Gururaja. 2012. Population crunch in India: is it urban or still rural? Current Science 103(1):37-40. [online] URL: http://www.currentscience.ac.in/Volumes/103/01/0037. pdf.

Sudhira, H. S., T. V. Ramachandra, and M. H. B. Subrahmanya. 2007. Bangalore. Cities 24(5):379-390. http://dx.doi.org/10.1016/ j.cities.2007.04.003

Sundaresan, J. 2011. Planning as commoning: transformation of a Bangalore lake. Economic and Political Weekly 46(50):71-79.

Swallow, B., N. Johnson, R. Meinzen-Dick, and A. Knox. 2006. The challenges of inclusive cross-scale collective action in watersheds. Water International 31(3):361-375. http://dx.doi. org/10.1080/02508060608691938

Theobald, D. M. 2004. Placing exurban land-use change in a human modification framework. Frontiers in Ecology and the Environment 2(3):139-144. http://dx.doi.org/10.1890/1540-9295 (2004)002[0139:PELCIA]2.0.CO;2

United Nations. 2011. World urbanization prospects: the 2010 revision. United Nations Department of Economic and Social Affairs, Population Division, New York, New York, USA. [online] URL: http://esa.un.org/unup/.
Wilson, J., L. Yan, and C. Wilson. 2007. The precursors of governance in the Maine lobster fishery. Proceedings of the National Academy of Sciences 104(39):15212-15217. http://dx. doi.org/10.1073/pnas.0702241104 


\section{Appendix 1.}

The seven lakes in our study were categorized into two groups (low and high) based on their environmental condition, as described further in the table below.

\begin{tabular}{|c|c|c|c|}
\hline Lake & $\begin{array}{l}\text { Restored } \\
\text { between } 2009 \\
\text { and } 2012 \\
\end{array}$ & Source & Details \\
\hline Agara & No & $\begin{array}{l}\text { High Court of } \\
\text { Karnataka } \\
(2011)\end{array}$ & $\begin{array}{l}\text { Categorized as a Class D lake, } \\
\text { i.e. polluted }\end{array}$ \\
\hline Ambalipura & Yes & $\begin{array}{l}\text { BBMP Lakes } \\
\text { Division }\end{array}$ & $\begin{array}{l}\text { Dry lake prior to restoration. } \\
\text { Following restoration, lake } \\
\text { water quality is considered } \\
\text { high, per the BBMP Lakes } \\
\text { Division }\end{array}$ \\
\hline Bellandur & No & $\begin{array}{l}\text { High Court of } \\
\text { Karnataka } \\
(2011)\end{array}$ & $\begin{array}{l}\text { Categorized as a Class D lake, } \\
\text { i.e. polluted }\end{array}$ \\
\hline Kaikondanahalli & Yes & $\begin{array}{l}\text { High Court of } \\
\text { Karnataka } \\
(2011) \text { and } \\
\text { BBMP Lakes } \\
\text { Division }\end{array}$ & $\begin{array}{l}\text { Categorized as a Class D lake, } \\
\text { i.e. polluted, prior to } \\
\text { restoration. Following } \\
\text { restoration, water quality in the } \\
\text { lake is considered good, per } \\
\text { information from BBMP Lakes } \\
\text { Division. }\end{array}$ \\
\hline Mestripalya & No & Field visit & $\begin{array}{l}\text { Completely dry lake, thus } \\
\text { categorized as in low } \\
\text { environmental condition. }\end{array}$ \\
\hline $\begin{array}{l}\text { Parappana } \\
\text { Agrahara }\end{array}$ & No & $\begin{array}{l}\text { High Court of } \\
\text { Karnataka } \\
(2011)\end{array}$ & $\begin{array}{l}\text { Categorized as a Class D lake, } \\
\text { i.e. polluted }\end{array}$ \\
\hline Varthur & No & $\begin{array}{l}\text { High Court of } \\
\text { Karnataka } \\
(2011)\end{array}$ & $\begin{array}{l}\text { Categorized as a Class E lake, } \\
\text { i.e. polluted }\end{array}$ \\
\hline
\end{tabular}




\section{Appendix 2.}

Detailed description of the SES attributes of the seven lakes studied in Bangalore, focusing largely on the time period between 2007 and 2012.

In the case of urban lakes, the variable that varied the most between different lakes was their size (RS3). Bellandur and Varthur are among the largest lakes in Bangalore, collecting water from a number of lakes in the network; indeed, Bellandur is the largest lake in the city limits, with an area just over 360 ha, while Varthur Lake is over 120 ha. The estimated cost of restoration of these lakes is Rs. 900,000,000 (approximately USD 16, 556, 291 at current rates of exchange) and Rs. 150,000,000 (approximately USD 2, 759, 381) respectively (BBMP 2010). Agara and Kaikondanahalli are moderate in size and extend to about 20 ha, while Ambalipura, Parappana Agrahara, and Mestripalya are small lakes with areas of 3-6 ha. Ambalipura and Kaikondanahalli have been recently restored at an approximate cost of Rs. 15,200,000 (approximately USD 279,617) and Rs. 108,500,000 (approximately USD 1,995,952) respectively (BBMP 2010), and do not have substantial amounts of sewage currently.

The number of actors (A2) is lowest in Mestripalya, with exclusion of socio-economic groups (A2a). This former lake has dried completely, and was converted into a park and nursery, with some encroachments for construction. A Public Interest Litigation filed by local residents and pursued diligently over a couple of decades resulted in a court ruling that the area was a lake, and could not be developed for any other purpose. A relatively small and reasonably cohesive group of local residents have worked with technical experts, and developed a plan for restoration that incorporates social and ecological considerations. This group is largely comprised of a small group of middle class and affluent residents, and does not include the inhabitants of adjacent villages in their deliberations. Restoration of the lake has recently begun in 2013 and is now in progress.

In Ambalipura, Kaikondanahalli, and Parappana Agrahara, the group of actors is moderate in size, and includes the original residents of the villages around these lakes - representing a diversity of uses including commercial and subsistence fishing, grazing, fodder collection, cattle washing, clothes washing, and firewood collection - and urban residents, both poor and wealthy, who access the lake for a range of purposes, from washing of clothes to urban recreation and exercise. The set of actors expands further in Bellandur and Varthur to additionally include a number of industries and some hospitals located around these lakes, which also impact the lake by polluting it and encroaching on the lake bed as well as the lake channels that drain into and out of the lake. Attempts at planning have included a diversity of actors including original village inhabitants, as well as actors belonging to educational institutions, and corporate establishments.

Strong local leadership (A5) exists in all four lakes where collective-action levels are high Ambalipura, Bellandur, Kaikondanahalli, and Mestripalya. The leadership does not vest with one strong (and therefore possibly autocratic) individual, but instead, a relatively small group of individuals have led different initiatives at different points of time, who may interact informally (as in the case of Kaikondanahalli Lake) or through a tightly linked, formalized network with defined responsibilities (as in the case of Mestripalya). In Agara, Parappana Agrahara, and Varthur, there have been sporadic efforts by influential local residents and groups to organize 
protests, but in Parappana Agrahara and Varthur these have not been sustained due to a lack of influential, widely accepted leadership. In Agara, a recent initiative by local residents in 2013 has led to cleaning up of the periphery of the lake, and the initiation of a new cycle of lake protection and restoration.

Norms of trust and social capital (A6) are low in Agara, Bellandur, and Varthur, where connections have not been established between older residents from different socioeconomic groups, and between residents from surrounding villages and relatively recent urban residents. In Mestripalya, although the local residents' association has worked together to reclaim the area from encroachment and to devise a community plan for restoration, there are some conflicts between members of this group, thus social capital is characterized as moderate in this lake. Ambalipura represents a landlocked lake surrounded by high-end apartments and layouts, and the social capital there is quite high. In Parappana Agrahara, at the periphery of the city where urbanization is relatively limited, the opposite holds true - social capital within the village is fairly high, and the involvement of urban residents is fairly low. In Kaikondanahalli, the group that works for restoration of the lake includes representation from older villages as well as from more recent houses and apartments, and social capital can be characterized as high.

Current dependence on the lake (A8) is low in Agara, where the lake has been degraded for the past few years, as well as in Mestripalya, where the lake bed has been dry for decades. In Ambalipura and Kaikondanahalli, the lake has become an important location for urban exercise and recreation in recent months, following their restoration. These lakes are also important for restoring the rapidly depleting water tables in this area. Their dependence on these lakes is, therefore, moderate. In Bellandur and Varthur, although recreation and exercise are not possible due to the high levels of pollution, the villages near these lakes depend on them for agriculture and cattle fodder (although these dependencies have decreased over time). Their drinking water also comes from wells that are linked to these lakes through a shared groundwater table, which results in pollution of their groundwater. Parappana Agrahara Lake has become extremely polluted in recent years due to sewage from the adjacent Bangalore Central Jail, but the village still depends on this water for agriculture, cattle fodder collection, cattle washing and other domestic uses. There are a number of wells linked to the groundwater supply that the adjacent villages rely on that have become polluted as a consequence of the lake pollution. Thus, the dependence of the residents surrounding these three lakes is extremely high.

In Ambalipura and Kaikondanahalli, just prior to restoration, there were no commonly accepted operational community rules (GS5) that placed a limit on the types of activities permitted in the lake. After restoration, however, the community associations maintaining the lake have developed an informal and evolving set of adaptive guidelines that indicate, for instance, how much fodder can be extracted from the lake during which seasons, and limit activities such as washing of clothes, dumping of solid waste, and input of sewage. In Agara, Bellandur, and Varthur, there is a current absence of operational rules, although such rules may have been in place earlier. In Mestripalya, since the lake bed was dry for several years and the park in existence in this area was overgrown with weeds and rarely visited, there was no need for the development or enforcement of operational rules. Once restoration is complete, this may change. In Parappana Agrahara, although there were operational rules and norms in place until recently that indicated permissible types of use and extraction by adjacent villages in line, many of these 
practices such as fishing and washing of cattle have been discontinued or heavily scaled down after the lake became polluted, and such use of the lake is so infrequent that again, there is no need for the maintenance or enforcement of operational rules.

Ambalipura and Kaikondanahalli have been especially successful at networking with government agencies (I8a). These are the two lakes where restoration has proceeded in a manner that pays attention to the social as well as the ecological requirements of residents, and where ecological outcomes are highest - indicating the importance of this variable. Informal norms related to monitoring (I9) are only in existence in two of the seven lakes - Ambalipura and Kaikondanahalli.

In terms of Outcome variables (O1), collective action is high in Ambalipura, Bellandur, Kaikondanahalli, and Mestripalya; moderate in Agara and Varthur, where some efforts have been made by local groups to protect and restore the lake; and low in Parappana Agrahara, where local residents have tried to organize to protest against the pollution of their lake by the Bangalore Central Jail, but have been unable to do this effectively and in a sustained manner. Ambalipura and Kaikondanahalli are relatively high in environmental condition $(\mathrm{O} 2)$. The other lakes are all low in environmental condition, as explained further in Appendix 1. 